\title{
Article \\ Exploring Electrochemically Mediated ATRP of Styrene
}

\author{
Francesco De Bon ${ }^{1,2}$, Gian Marco Carlan ${ }^{1}$, Enrico Tognella ${ }^{1}$ (D) and Abdirisak Ahmed Isse ${ }^{1, *}$ (D) \\ 1 Department of Chemical Sciences, University of Padova, Via Marzolo 1, 35131 Padova, Italy; \\ francesco.debon91@gmail.com (F.D.B.); gm.carlan@outlook.it (G.M.C.); \\ enrico.tognella@studenti.unipd.it (E.T.) \\ 2 Centre for Mechanical Engineering Materials and Processes (CEMMPRE), Department of Chemical \\ Engineering, University of Coimbra, Rua Sílvio Lima, Pólo II, 3030-790 Coimbra, Portugal \\ * Correspondence: abdirisak.ahmedisse@unipd.it
}

check for updates

Citation: De Bon, F.; Carlan, G.M.; Tognella, E.; Isse, A.A. Exploring Electrochemically Mediated ATRP of Styrene. Processes 2021, 9, 1327. https://doi.org/10.3390/pr9081327

Academic Editors: Carmen Boeriu, Francesca Lorandi and Sajjad Dadashi Silab

Received: 9 July 2021

Accepted: 28 July 2021

Published: 30 July 2021

Publisher's Note: MDPI stays neutral with regard to jurisdictional claims in published maps and institutional affiliations.

Copyright: (c) 2021 by the authors. Licensee MDPI, Basel, Switzerland. This article is an open access article distributed under the terms and conditions of the Creative Commons Attribution (CC BY) license (https:// creativecommons.org/licenses/by/ $4.0 /)$.

\begin{abstract}
Electrochemically mediated atom transfer radical polymerization (eATRP) of styrene was studied in detail by using $\mathrm{CuBr}_{2}$ /TPMA (TPMA = tris(2-pyridylmethyl)amine) as a catalyst. Redox properties of various $\mathrm{Cu}(\mathrm{II})$ species were investigated in $\mathrm{CH}_{3} \mathrm{CN}$, dimethylformamide (DMF), and dimethyl sulfoxide (DMSO) both in the absence and presence of $50 \%(v / v)$ styrene. This investigation together with preliminary eATRP experiments at $80{ }^{\circ} \mathrm{C}$ indicated DMF as the best solvent. The effects of catalyst, monomer, and initiator concentrations were also examined. The livingness of the polymerization was studied by chain extension and electrochemical temporal control of polymerization.
\end{abstract}

Keywords: styrene; eATRP; temporal control; copper catalyst

\section{Introduction}

Atom transfer radical polymerization (ATRP) is one of the most preferred macromolecular engineering techniques owing to its facile setup, tolerance to a large extent of functional groups, often mild reaction conditions, and a vast number of applications [1,2]. Various ATRP techniques such as initiators for continuous activator regeneration (ICAR) ATRP [3,4], activators regenerated by electron transfer (ARGET) ATRP [5-8], supplemental activators and reducing agents (SARA) ATRP [9-12], photoATRP [13-15], photoinduced metal-free ATRP [16-18], electrochemically mediated ATRP (eATRP) [19-24], and mechanoATRP [25-27] permitted facile and well-controlled polymerizations of a vast variety of monomers with low amounts of metal catalyst or with no metal catalyst at all.

A redox equilibrium involving a transition metal complex regulates the polymerization process, using various metals [28]. The most active and widely used catalysts are copper complexes with multidentate nitrogen-based ligands [29]. A general mechanism of coppercatalyzed ATRP with electrochemical regeneration of $\mathrm{Cu}^{\mathrm{I}}$ activator complex is shown in Scheme 1. The process is initiated by an inner-sphere electron transfer involving the transfer of a halogen atom from an alkyl halide initiator, $\mathrm{RX}$, or a halogen-capped dormant chain, $\mathrm{P}_{\mathrm{n}^{-}}$ $\mathrm{X}$, to $\left[\mathrm{Cu}^{\mathrm{I}} \mathrm{L}\right]^{+}\left(\mathrm{L}=\right.$ a nitrogen-based ligand), whereby the $\left[\mathrm{XCu}^{\mathrm{II}} \mathrm{L}\right]^{+}$deactivator and a carboncentered radical are formed [30-32]. The latter propagates with a rate constant $k_{\mathrm{p}}$ by adding to a few monomer units before reacting with $\left[\mathrm{XCu}^{\mathrm{II}} \mathrm{L}\right]^{+}$to produce a dormant polymer chain and $\left[\mathrm{Cu}^{\mathrm{I}} \mathrm{L}\right]^{+}$. Dormant polymers play a crucial role in controlled polymerizations [33]. A well-controlled polymerization requires the equilibrium to be strongly shifted to the left, with an equilibrium constant $K_{\mathrm{ATRP}}=k_{\text {act }} / k_{\text {deact }}<<1$, to reduce the concentration of radicals and retain chain-end functionality. $K_{\text {ATRP }}$ is generally very small in organic solvents but spans a wide range of values $\left(10^{-4}-10^{-12}\right)$ because it is sensible to temperature, pressure, solvent, polymer chain-end structure, and type of catalyst [34-38]. Besides propagation with $k_{\mathrm{p}}$ and deactivation with $k_{\text {deact }}, \mathrm{P}_{\mathrm{n}} \bullet$ can undergo termination reactions with a rate constant $k_{\mathrm{t}}$. Although $k_{\mathrm{t}}$ is near the diffusion limit, the rate of termination reactions in ATRP is very low because of low $\left[\mathrm{P}_{\mathrm{n}}^{\bullet}\right]$ [1]. Nevertheless, continuous slow termination during 
polymerization accumulates the catalyst in the deactivator form, i.e., $\left[\mathrm{XCu}^{\mathrm{II}} \mathrm{L}\right]^{+}$, which must be reduced back to $\left[\mathrm{Cu}^{\mathrm{I}} \mathrm{L}\right]^{+}$to avoid reaction blockage. In electrochemically mediated ATRP, the activator form of the catalyst is regenerated by electrochemical reduction of $\left[\mathrm{XCu}^{\mathrm{II}} \mathrm{L}\right]^{+}$to $\left[\mathrm{Cu}^{\mathrm{I}} \mathrm{L}\right]^{+}$(Scheme 1$)$.

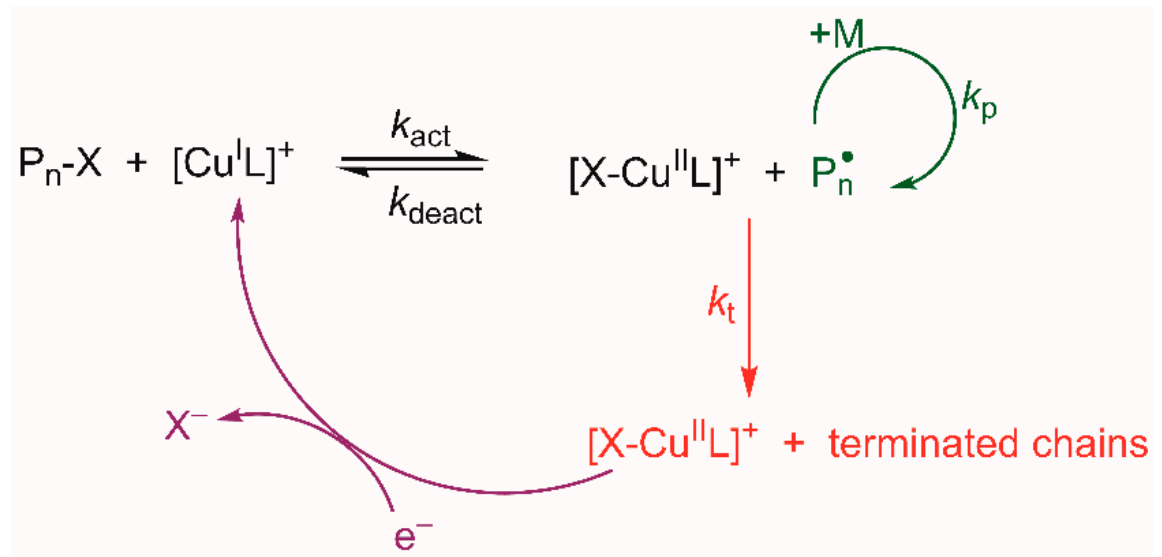

Scheme 1. Mechanism of ATRP with electrochemical regeneration of the activator complex (eATRP).

Electrochemistry has demonstrated in the last years its extraordinary power in regenerating $\mathrm{Cu}^{\mathrm{I}}$ species from $\mathrm{Cu}{ }^{\mathrm{II}}$ complexes, with the exclusive benefit of avoiding formation of by-products, as electrons are used in lieu of chemical reducing agents [23,24]. Furthermore, the ratio between $\mathrm{Cu}^{\mathrm{II}}$ deactivator and $\mathrm{Cu}^{\mathrm{I}}$ species is fixed by the applied potential, therefore it can be finely tuned by modulating the electrochemical stimulus. This technique, known as eATRP was applied to several monomers in organic solvents, [39-46] water [47-54], miniemulsions [55-57], and ionic liquids [58,59].

Polystyrene (PS) is one of the most widely used plastics with a global production rate of several million tons per year. ATRP of styrene appeared for the first time in 1995 in the pioneering work of Matyjaszewski and Wang [60], and up to now it has been polymerized by almost all ATRP techniques, including conventional ATRP [60-62], ICAR ATRP [63-65], AGET and ARGET ATRP [8,66-70], SARA ATRP [71-74], and photo-induced ATRP [15,75-77]. Electrochemically mediated ATRP of styrene was instead not explored, apart from a preliminary study back in 2009 on $\mathrm{Fe}^{\mathrm{II}}$ (Salen)-catalyzed polymerization, which appears to follow a reaction pathway involving an organometallic intermediate rather the typical ATRP mechanism [78]. It is known that styrene polymerization is hampered by its low propagation rate constant $\left(k_{\mathrm{p}}\right)$ [79] and usually high temperatures, typically above $100{ }^{\circ} \mathrm{C}$, are used to polymerize it with a decent rate. This may appear to limit the possibility of $e$ ATRP due to the harsh conditions to which the electrodes are exposed. Herein, we wish to show that $e$ ATRP can be successfully applied to styrene. Our primary goal was to find an optimized set of conditions which provide polystyrene with a narrow molecular weight distribution and predefined molecular weight in a reasonably short time. The reaction was investigated in different solvents using $\mathrm{CuBr}_{2} / \mathrm{TPMA}$ (TPMA $=\operatorname{tris}(2-$ pyridylmethyl)amine) as a catalyst and ethyl 2-bromoisobutyrrate (EBiB) as an initiator.

\section{Materials and Methods}

\subsection{Materials}

All solvents (DMF, $\mathrm{CH}_{3} \mathrm{CN}$, and DMSO, Sigma-Aldrich, Darmstadt, Germany) were of high purity and used without further purification. Copper(II) trifluoromethanesulfonate $\left(\mathrm{Cu}(\mathrm{OTf})_{2}\right.$, Sigma-Aldrich, Darmstadt, Germany, 98\%), copper(II) bromide $\left(\mathrm{CuBr}_{2}\right.$, Sigma Aldrich, 99.999\% trace metal basis), tris(2-pyridylmethyl)amine (TPMA, Sigma-Aldrich, Darmstadt, Germany, 98\%), ethyl 2-bromoisobutyrrate (EBiB, Sigma Aldrich, Darmstadt, Germany, 98\%), $\mathrm{H}_{2} \mathrm{SO}_{4}$ (Fluka, Buchs, Switzerland, 95\%, TraceSELECT), tetrabutylammonium chloride $\left(\mathrm{Bu}_{4} \mathrm{NCl}\right.$, Aldrich, Darmstadt, Germany, $\left.98 \%\right)$, and tetrabutylammonium tetrafluoroborate $\left(\mathrm{Bu}_{4} \mathrm{NBF}_{4}\right.$, Aldrich, Darmstadt, Germany, $\left.98 \%\right)$ were used as received. 
Styrene (Sigma-Aldrich, Darmstadt, Germany, $>99 \%$ ) was purified by passing through a column filled with active basic aluminum oxide $\left(\mathrm{Al}_{2} \mathrm{O}_{3}\right.$, VWR chemicals, Milano, Italy) in the dark to remove polymerization inhibitors and stored at $-20{ }^{\circ} \mathrm{C}$ in an amber bottle. Tetraethylammonium bromide ( $\mathrm{Et}_{4} \mathrm{NBr}$, Sigma-Aldrich, Darmstadt, Germany, $99 \%$ ) was recrystallized from acetone. Tetraethylammonium tetrafluoroborate $\left(\mathrm{Et}_{4} \mathrm{NBF}_{4}\right.$, Alfa Aesar, Kandel, Germany, 99\%) used as a supporting electrolyte was recrystallized twice from ethanol. After recrystallization, both salts were dried in a vacuum oven at $70{ }^{\circ} \mathrm{C}$ for $48 \mathrm{~h}$.

\subsection{Instrumentation}

Electrochemical studies on the $\mathrm{Cu}$ catalyst were carried out in a 5-neck electrochemical cell, equipped with three electrodes, and connected to an Autolab PGSTAT 30 potentiostat/galvanostat (EcoChemie, Utrecht, The Netherlands) run by a PC with GPES software (EcoChemie). Electrosynthesis of polystyrene was carried out in a 5-neck electrochemical cell, equipped with three electrodes, connected to a PAR273A potentiostat/galvanostat (Princeton Applied Research, Oak Ridge, USA) run by a PC with Echem software. A glassy carbon (GC) disk, fabricated from a 3-mm diameter rod (Tokai GC-20, Tokyo, Japan), was used as a working electrode for cyclic voltammetry (CV). Before each experiment, the disk was cleaned by polishing with a $0.25-\mu \mathrm{m}$ diamond paste, followed by ultrasonic rinsing in ethanol for $5 \mathrm{~min}$. The working electrode employed for electrolysis was a Pt mesh (Alfa Aesar, Kandel, Germany, $99.9 \%$ metals basis) with a geometric area of approximately $6 \mathrm{~cm}^{2}$, which was electrochemically activated prior to each experiment by cycling the potential from $-0.7 \mathrm{~V}$ to $1 \mathrm{~V}$ vs. $\mathrm{Hg} \mid \mathrm{Hg}_{2} \mathrm{SO}_{4}$ at a scan rate of $0.2 \mathrm{~V} \mathrm{~s}^{-1}$ (60 cycles). The counter electrode was a $\mathrm{Pt}$ wire in $\mathrm{CV}$, whereas a graphite rod was used for electrolysis. In the latter case, the electrode was separated from the working solution by a glass frit filled with the same electrolyte solution used in the working electrode compartment and a methylcellulose gel saturated with $\mathrm{Et}_{4} \mathrm{NBF}_{4}$. The reference electrode was $\mathrm{Ag}|\mathrm{AgI}| \mathrm{I}^{-}$ $0.1 \mathrm{M} \mathrm{n}-\mathrm{Bu}_{4} \mathrm{NI}$ in DMF. Ferrocene $(\mathrm{Fc})$ was added at the end of each experiment as an internal standard, so that all potentials are referred to the ferrocenium/ferrocene $\left(\mathrm{Fc}^{+} \mid \mathrm{Fc}\right)$ redox couple. The cell was thermostated at $25{ }^{\circ} \mathrm{C}$ or $80{ }^{\circ} \mathrm{C}$, and all experiments were performed under inert atmosphere $\left(\mathrm{N}_{2}\right.$ or $\left.\mathrm{Ar}\right)$. The number average molecular weight $\left(M_{n}\right)$ and dispersity $(\nexists)$ values were determined by gel permeation chromatography (GPC) with an Agilent 1260 Infinity GPC, equipped with a refractive index (RI) detector and two PLgel Mixed-D columns ( $300 \mathrm{~mm}, 5 \mu \mathrm{m}$ ) connected in series. The column compartment and RI detector were thermostated at $35^{\circ} \mathrm{C}$. The eluent was stabilized THF, at a flow rate of $1 \mathrm{~mL} / \mathrm{min}$. The column system was calibrated with 10 linear polystyrene (PS) standards $\left(M_{\mathrm{n}}=162-371,100 \mathrm{Da}\right)$. Monomer conversion was determined by ${ }^{1} \mathrm{H}-\mathrm{NMR}$ spectroscopy with a $200 \mathrm{MHz}$ Bruker Avance instrument, using $\mathrm{CDCl}_{3}$ as a solvent.

\subsection{Procedures}

\subsubsection{Typical Procedure for $e$ ATRP of Styrene}

The electrochemical cell was flushed with $\mathrm{N}_{2}$ and loaded with $5 \mathrm{~mL}$ of DMF, $5 \mathrm{~mL}$ of styrene, $2.2 \mathrm{mg}$ of $\mathrm{CuBr}_{2}$, and $2.92 \mathrm{mg}$ of TPMA under a flow of the inert gas. After heating the cell to $80^{\circ} \mathrm{C}$ with a water bath, a CV of the catalyst was recorded to measure its standard reduction potential. Then $22 \mu \mathrm{L}$ of $\mathrm{EBiB}$ was injected and a CV was recorded. Polymerization was started by applying the selected applied potential $\left(E_{\mathrm{app}}\right)$ and samples were withdrawn periodically to measure monomer conversion, and $M_{n}$ and $\boxminus$ of the polymer.

\subsubsection{Preparation of PS-Br Macroinitiator}

A cell under $\mathrm{N}_{2}$ flux was loaded with $2.5 \mathrm{~mL}$ of DMF, $2.2 \mathrm{mg}$ of $\mathrm{CuBr}_{2}, 2.94 \mathrm{mg}$ of TPMA, and $7.5 \mathrm{~mL}$ of styrene. After degassing the mixture with $\mathrm{N}_{2}$ for at least $15 \mathrm{~min}$, the cell was heated to $80^{\circ} \mathrm{C}$ with a water bath and the $\mathrm{CV}$ was recorded. Then $22 \mu \mathrm{L}$ of $\mathrm{EBiB}$ was injected and the $\mathrm{CV}$ was recorded. The polymerization was then started by applying $E_{\mathrm{app}}=E_{1 / 2}$. The reaction was stopped after $2 \mathrm{~h}$, and the polymer was precipitated into methanol and isolated by filtration. The polymer was washed twice with methanol 
and dried under vacuum for several hours at $50{ }^{\circ} \mathrm{C}$. The final weight PS-Br $\left(M_{n}=10,900\right.$, $\Xi=1.14)$, recovered as a white powder, was $1.0 \mathrm{~g}$.

\subsubsection{Procedure for Temporally Controlled $e$ ATRP}

The cell was prepared with all reagents as previously described for $e$ ATRP of styrene. Polymerization was then started by applying $E_{\mathrm{app}}=E_{1 / 2}$. After $1 \mathrm{~h}$ of reaction, the potential was set off and the cell remained disconnected from the electric circuit for $1 \mathrm{~h}$ after which $E_{\text {app }}=E_{1 / 2}$ was set again for $1 \mathrm{~h}$, followed by another OFF period and a final $1 \mathrm{~h}$ of applied potential. Samples were withdrawn at the end of each step to measure monomer conversion, and molecular weight and $\boxminus$ of the polymer.

\subsubsection{Chain Extension of PS-Br by eATRP}

The cell was prepared with all reagents as previously described for $e$ ATRP of styrene except for using $0.2 \mathrm{~g}$ of PS-Br $\left(M_{n}=10,900, \boxminus=1.14\right)$ as a macroinitiator. Chain extension was performed by applying $E_{\mathrm{app}}=E_{1 / 2}$ for $3 \mathrm{~h}$. The final polymer had $M_{\mathrm{n}}=24.9 \mathrm{kDa}$ and $Ð=1.17$.

\section{Results and Discussion}

\subsection{Voltammetric Behavior of the Catalyst}

The copper catalyst is prepared in situ as $\left[\mathrm{BrCu}^{\mathrm{II}} \mathrm{TPMA}\right]^{+}$by mixing equimolar amounts of $\mathrm{CuBr}_{2}$ and TPMA and the activator form, $\left[\mathrm{Cu}^{\mathrm{I}} \mathrm{TPMA}\right]^{+}$, is electrogenerated during polymerization. To evaluate the redox properties of the catalyst and the relative stabilities of $\mathrm{Cu}^{\mathrm{II}}$ and $\mathrm{Cu}^{\mathrm{I}}$ complexes, both $\left[\mathrm{BrCu}{ }^{\mathrm{II}} \mathrm{TPMA}\right]^{+}$and $\left[\mathrm{Cu}^{\mathrm{II}} \mathrm{TPMA}\right]^{2+}$ were investigated by cyclic voltammetry $(\mathrm{CV})$. The standard potentials of solvated copper ions were also estimated by cyclic voltammetry of $\mathrm{Cu}(\mathrm{OTf})_{2}$ in the absence of added TPMA and $\mathrm{Br}^{-}$. Typical CV responses of all investigated $\mathrm{Cu}^{\mathrm{II}}$ species in DMF, DMSO, and $\mathrm{CH}_{3} \mathrm{CN}$ as well as in 50\% $(v / v)$ solvent/styrene mixtures are reported in Figure 1. The observed peak couple stands for a one-electron transfer process involving the $\mathrm{Cu}^{\mathrm{II}} / \mathrm{Cu}^{\mathrm{I}}$ redox couple. This allows easy determination of the standard potential as the half sum of the cathodic and anodic peak potentials, $E_{\mathrm{pc}}$ and $E_{\mathrm{pa}}$, respectively: $E^{\circ} \approx E_{1 / 2}=\left(E_{\mathrm{pc}}+E_{\mathrm{pa}}\right) / 2$. The differences in current intensities are ascribed to changes of the diffusion coefficients of $\mathrm{Cu}^{\mathrm{II}}$ species in different media.

The voltammetric pattern shown in Figure 1 did not change with the scan rate $(v)$, except the current intensity which was proportional to $v^{1 / 2}$ and the separation between the cathodic and anodic peaks, which increased with increasing $v$. These findings clearly indicate that $\mathrm{Cu}^{\mathrm{II}}$ undergoes a diffusion-controlled quasi-reversible electron transfer. Notably, although $\Delta E_{\mathrm{p}}=E_{\mathrm{pc}}-E_{\mathrm{pa}}$ increased with increasing $v, E_{1 / 2}$ was independent of the scan rate. Therefore, $E^{\circ}$ was calculated for each redox couple as the average of the values measured at different scan rates in the range from $0.01 \mathrm{~V} / \mathrm{s}$ to $1 \mathrm{~V} / \mathrm{s}$ and the results are reported in Table 1. $\Delta E_{\mathrm{p}}$ values measured at different scan rates were used to determine the standard rate constants of electron transfer $\left(k^{\circ}\right)$ for $\left[\mathrm{Cu}{ }^{\mathrm{II}} \mathrm{TPMA}\right]^{2+}$ and $\left[\mathrm{BrCu}{ }^{\mathrm{II}} \mathrm{TPMA}\right]^{+}$according to the method of Nicholson [80]. $k^{\circ}$ values in the range $2.8 \times 10^{-2}-1.0 \times 10^{-1} \mathrm{~cm} / \mathrm{s}$ were observed in pure solvents (Table 1 ). In general $k^{\circ}$ increased in the order DMSO $<\mathrm{DMF}<$ $\mathrm{CH}_{3} \mathrm{CN}$, roughly in agreement with the predicted dependence of $k^{\circ}$ on the longitudinal relaxation time of the solvent [81]. Addition of 50\% styrene to the solvents decreased the standard rate constant of electron transfer. 

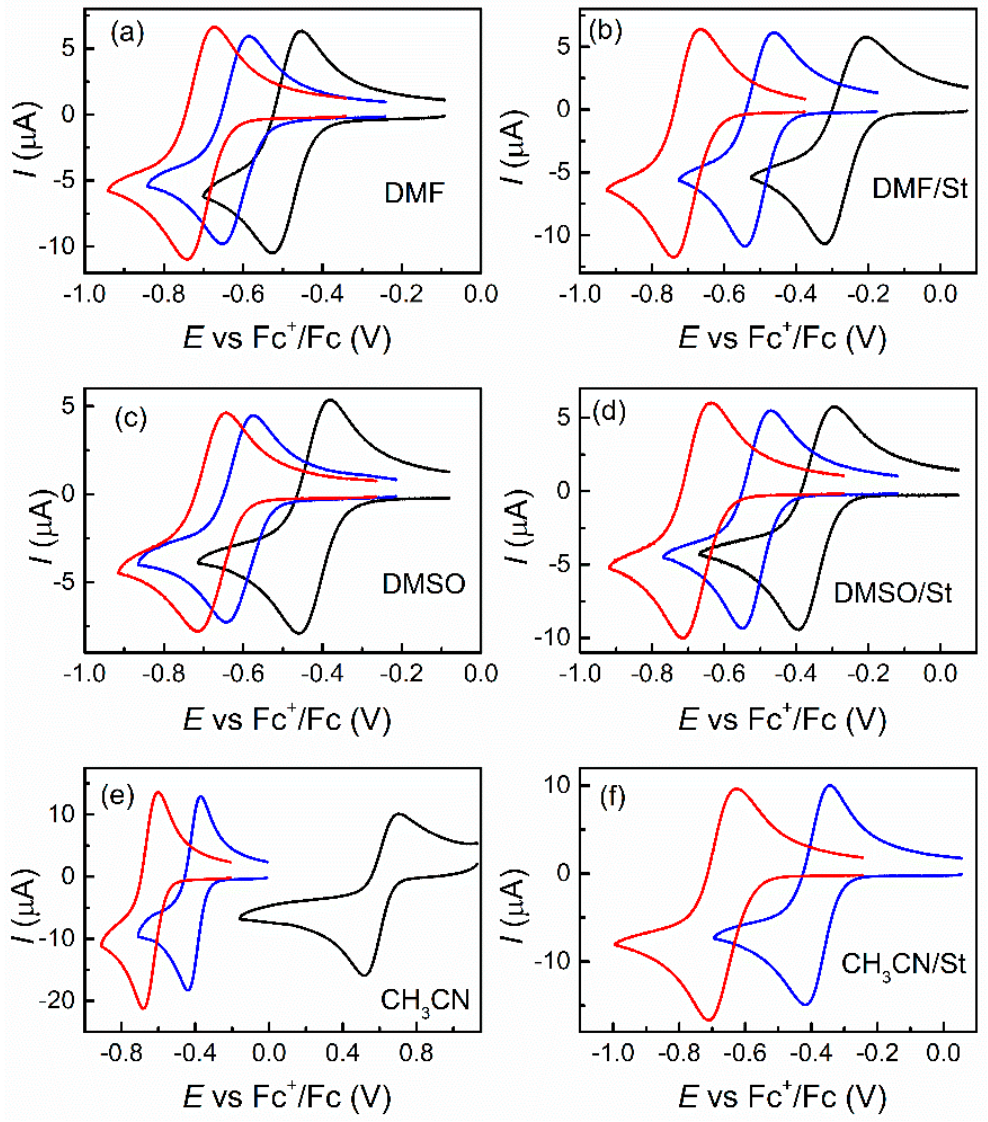

Figure 1. Cyclic voltammetry of $10^{-3} \mathrm{M} \mathrm{Cu}^{\mathrm{II}}(\mathrm{OTf})_{2}(-),\left[\mathrm{Cu}^{\mathrm{II}} \mathrm{TPMA}\right]^{2+}(-)$ and $\left[\mathrm{BrCu}^{\mathrm{II}} \mathrm{TPMA}\right]^{+}$ $(-)$ in pure solvents $(\mathbf{a}, \mathbf{c}, \mathbf{e})$ and $50 \%(v / v)$ solvent/styrene mixtures $(\mathbf{b}, \mathbf{d}, \mathbf{f}))$ containing $0.1 \mathrm{M} \mathrm{Et}_{4} \mathrm{NBF}_{4}$ as a supporting electrolyte, recorded on a GC electrode at $0.1 \mathrm{~V} / \mathrm{s}$ and $T=25^{\circ} \mathrm{C}$.

Table 1. Redox properties of copper complexes and their relative stabilities in different media at $25^{\circ} \mathrm{C}$.

\begin{tabular}{|c|c|c|c|c|c|}
\hline Solvent ${ }^{1}$ & $\mathrm{Cu}(\mathrm{II})$ & $\begin{array}{c}E^{\circ 2} \\
(\mathrm{~V})\end{array}$ & $\begin{array}{l}10^{2} \times k^{\circ} \\
\left(\mathrm{cm} \mathrm{s}^{-1}\right)\end{array}$ & $\beta^{I I} / \beta^{I}$ & $K_{\mathrm{Br}}{ }^{\mathrm{II}} / K_{\mathrm{Br}} \mathrm{I}$ \\
\hline $\mathrm{DMF}$ & $\mathrm{Cu}(\mathrm{OTf})_{2}$ & -0.486 & & & \\
\hline DMF & {$[\mathrm{CuTPMA}]^{2+}$} & -0.621 & 2.8 & $1.89 \times 10^{2}$ & \\
\hline DMF & 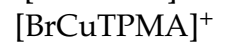 & -0.708 & 4.4 & & 29.9 \\
\hline DMSO & $\mathrm{Cu}(\mathrm{OTf})_{2}$ & -0.418 & & & \\
\hline DMSO & {$[\mathrm{CuTPMA}]^{2+}$} & -0.615 & 1.6 & $2.14 \times 10^{3}$ & \\
\hline DMSO & 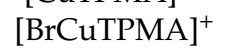 & -0.687 & 2.3 & & 16.5 \\
\hline $\mathrm{CH}_{3} \mathrm{CN}$ & $\mathrm{Cu}(\mathrm{OTf})_{2}$ & 0.611 & & & \\
\hline $\mathrm{CH}_{3} \mathrm{CN}$ & {$[\mathrm{CuTPMA}]^{2+}$} & -0.408 & 7.5 & $1.67 \times 10^{17}$ & \\
\hline $\mathrm{CH}_{3} \mathrm{CN}$ & 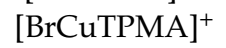 & -0.658 & 10 & & $1.69 \times 10^{4}$ \\
\hline $\mathrm{DMF} / \mathrm{St}$ & $\mathrm{Cu}(\mathrm{OTf})_{2}$ & -0.266 & & & \\
\hline $\mathrm{DMF} / \mathrm{St}$ & {$[\mathrm{CuTPMA}]^{2+}$} & -0.505 & 0.8 & $1.10 \times 10^{4}$ & \\
\hline $\mathrm{DMF} / \mathrm{St}$ & 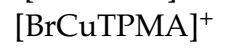 & -0.710 & 3.0 & & $2.92 \times 10^{3}$ \\
\hline $\mathrm{DMSO} / \mathrm{St}$ & $\mathrm{Cu}(\mathrm{OTf})_{2}$ & -0.346 & & & \\
\hline $\mathrm{DMSO} / \mathrm{St}$ & {$[\text { CuTPMA] }]^{2+}$} & -0.514 & 0.7 & $6.92 \times 10^{2}$ & \\
\hline $\mathrm{DMSO} / \mathrm{St}$ & 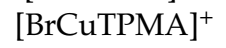 & -0.693 & 2.4 & & $1.05 \times 10^{3}$ \\
\hline $\mathrm{CH}_{3} \mathrm{CN} / \mathrm{St}$ & $\mathrm{Cu}(\mathrm{OTf})_{2}$ & - & & - & \\
\hline $\mathrm{CH}_{3} \mathrm{CN} / \mathrm{St}$ & {$[\mathrm{CuTPMA}]^{2+}$} & -0.384 & 1.6 & & \\
\hline $\mathrm{CH}_{3} \mathrm{CN} / \mathrm{St}$ & 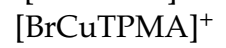 & -0.683 & 7.4 & & $1.13 \times 10^{5}$ \\
\hline
\end{tabular}

${ }^{1} \mathrm{St}=$ styrene; solvent/monomer mixtures were $50 / 50(v / v) .{ }^{2} \mathrm{vs} \mathrm{Fc}^{+} / \mathrm{Fc}$ couple. 
The standard reduction potentials of $\mathrm{Cu}^{2+},\left[\mathrm{Cu}^{\mathrm{II}} \mathrm{TPMA}\right]^{2+}$, and $\left[\mathrm{BrCu}{ }^{\mathrm{II}} \mathrm{TPMA}\right]^{+}$can be used to evaluate the relative stabilities of $\mathrm{Cu}^{\mathrm{I}}$ and $\mathrm{Cu} \mathrm{u}^{\mathrm{II}}$ complexes with TPMA and their relative affinities for $\mathrm{Br}^{-}$, according to Equations (1) and (2):

$$
\begin{gathered}
E_{\left[\mathrm{Cu}^{\mathrm{II}} \mathrm{L}\right]^{2+} /\left[\mathrm{Cu}{ }^{\mathrm{I} L}\right]^{+}}^{\mathrm{o}}=E_{\mathrm{Cu}^{2+} / \mathrm{Cu}^{+}}^{\mathrm{o}}-\frac{R T}{F} \ln \frac{\beta^{\mathrm{II}}}{\beta^{\mathrm{I}}} \\
E_{\left[\mathrm{BrCu}^{\mathrm{II}} \mathrm{L}\right]^{+} /\left[\mathrm{BrCu}^{\mathrm{I}} \mathrm{L}\right]}^{\mathrm{o}}=E_{\left[\mathrm{Cu}^{\mathrm{II}} \mathrm{L}\right]^{2+} /\left[\mathrm{Cu}^{\mathrm{I}} \mathrm{L}\right]^{+}}^{\mathrm{O}}-\frac{R T}{F} \ln \frac{K_{\mathrm{Br}}^{\mathrm{II}}}{K_{\mathrm{Br}}^{\mathrm{I}}}
\end{gathered}
$$

where $\beta^{\mathrm{I}}$ and $\beta^{\mathrm{II}}$ are the stability constants of $\left[\mathrm{Cu}^{\mathrm{I}} \mathrm{TPMA}\right]^{+}$and $\left[\mathrm{Cu}{ }^{\mathrm{II}} \mathrm{TPMA}\right]^{2+}$, respectively, defined as the formation equilibrium constants of the complexes from the solvated copper ions and the ligand. $K_{\mathrm{Br}}^{\mathrm{II}}$ and $K_{\mathrm{Br}}^{\mathrm{I}}$ are the binding constants of $\mathrm{Br}^{-}$to [Cu$\left.{ }^{\mathrm{II}} \mathrm{TPMA}\right]^{2+}$ and $\left[\mathrm{Cu}^{\mathrm{I} T P M A}\right]^{+}$, respectively; they express the halidophilicities of the $\mathrm{Cu}$ II/I $/ \mathrm{TPMA}$ complexes. This type of analysis was previously applied to $\mathrm{Cu}$ II/I $/$ TPMA complexes but was limited to the determination of $K_{\mathrm{Br}}{ }^{\mathrm{II}} / K_{\mathrm{Br}}{ }^{\mathrm{I}}$ in pure solvents [82]. Here, we consider both pure solvents and solvent/styrene mixtures and extend the analysis to the calculation of $\beta^{\mathrm{II}} / \beta^{\mathrm{I}}$. Calculated values of $\beta^{\mathrm{II}} / \beta^{\mathrm{I}}$ and $K_{\mathrm{Br}}{ }^{\mathrm{II}} / K_{\mathrm{Br}}{ }^{\mathrm{I}}$ are listed in Table 1 . In all reaction media, $\beta^{\mathrm{II}}>>\beta^{\mathrm{I}}$ but neither the effect of solvent type nor that of $50 \mathrm{vol} \%$ of styrene can be easily rationalized. Moreover, $K_{\mathrm{Br}}{ }^{\mathrm{II}}$ is always greater than $K_{\mathrm{Br}}{ }^{\mathrm{I}}$ and the higher affinity of $\mathrm{Br}^{-}$for $\left[\mathrm{Cu}^{\mathrm{II}} \mathrm{TPMA}\right]^{2+}$ than $\left[\mathrm{Cu}^{\mathrm{I}} \mathrm{TPMA}\right]^{+}$further increases in the presence of styrene. This is particularly important because it is desirable to have a deactivator complex $\left(\left[\mathrm{XCu}{ }^{\mathrm{II}} \mathrm{L}\right]^{+}\right)$ with good stability while the activator complex should not have high affinity for halide ions to avoid speciation of $\mathrm{Cu}^{\mathrm{I}}$ to produce inactive species $[30,83]$.

The $\beta^{\mathrm{II}} / \beta^{\mathrm{I}}$ and $K_{\mathrm{Br}}{ }^{\mathrm{II}} / K_{\mathrm{Br}}^{\mathrm{I}}$ values of Table 1 can be used to calculate the values of $\beta^{\mathrm{II}}, \beta^{\mathrm{I}}$ $K_{\mathrm{Br}}{ }^{\mathrm{II}}$, and $K_{\mathrm{Br}}{ }^{\mathrm{I}}$ provided that one of the values in each ratio is known. Unfortunately, there are no data on the stability constants, whereas some values of $K_{\mathrm{Br}}{ }^{\mathrm{II}}$ in pure solvents are available in the literature. Zerk and Bernhardt [84] reported $K_{\mathrm{Br}}{ }^{\mathrm{II}}$ values of $3.47 \times 10^{7} \mathrm{M}^{-1}$ and $1.1 \times 10^{5} \mathrm{M}^{-1}$ in $\mathrm{CH}_{3} \mathrm{CN}$ and DMSO, respectively, whereas Fantin et al. [85] reported $K_{\mathrm{Br}}^{\mathrm{II}}=4.2 \times 10^{5} \mathrm{M}^{-1}$ in DMF. These values give $K_{\mathrm{Br}}^{\mathrm{I}}=1.4 \times 10^{4} \mathrm{M}^{-1}, 6.7 \times 10^{2} \mathrm{M}^{-1}$ and $2.0 \times 10^{3} \mathrm{M}^{-1}$ in DMF, DMSO, and $\mathrm{CH}_{3} \mathrm{CN}$, respectively.

\subsection{Electrochemically Mediated ATRP of Styrene}

All polymerizations were carried out at $T=80^{\circ} \mathrm{C}$ to guarantee a decent polymerization rate. The catalyst was $\left[\mathrm{BrCu}{ }^{\mathrm{II}} \mathrm{TPMA}\right]^{+}$, prepared in situ by mixing equimolar amounts of $\mathrm{CuBr}_{2}$ and TPMA in the chosen solvent/styrene mixture. Ethyl $\alpha$-bromoisobutyrate (EBiB) was used as an initiator. Before starting the polymerization, cyclic voltammetry of the system was always performed on a glassy carbon electrode to measure the formal reduction potential of the catalyst and evaluate the effect of the initiator. Figure 2 shows an example of the voltammetric behavior of $\left[\mathrm{BrCu}^{\mathrm{II}} \mathrm{TPMA}\right]^{+}$in the presence of excess initiator. Addition of $\mathrm{EBiB}$ in a 15-fold excess with respect to the catalyst considerably changed the voltammetric response: the cathodic peak increased, while the anodic one almost disappeared. These changes are consistent with the catalytic activation of the initiator by electrogenerated $\mathrm{Cu}^{\mathrm{I}}$. Reduction of [BrCu ${ }^{\mathrm{II}} \mathrm{TPMA}^{+}$at the electrode produces [BrCu ${ }^{\mathrm{I}} \mathrm{TPMA}$ (Equation (3)), which

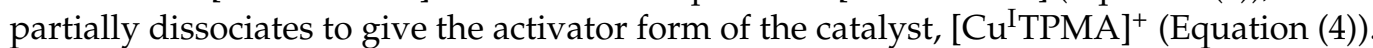
Reaction of the latter with the initiator $\mathrm{EBiB}$ regenerates the starting $\mathrm{Cu}^{\mathrm{II}}$ species together with a radical (Equation (5)), which either terminates by radical-radical coupling and disproportionation or is deactivated after a short period of propagation. During a cyclic voltammetry experiment, these reactions occur in a thin reaction layer adjacent to the electrode. Therefore, the $\mathrm{Cu}{ }^{\mathrm{II}}$ species generated by reaction 5 , easily reaches the electrode where it is reduced again to $\mathrm{Cu}^{\mathrm{I}}$ (Equation (3)). Depending on the kinetics of the activation reaction, this sequence may be repeated several times, leading to an increase of the cathodic peak current and a decrease or disappearance of the anodic one. 


$$
\begin{gathered}
{\left[\mathrm{BrCu}^{\mathrm{II} T P M A}\right]^{+}+\mathrm{e}^{-} \rightleftarrows\left[\mathrm{BrCu}^{\mathrm{I} T P M A}\right]} \\
{\left[\mathrm{BrCu}^{\mathrm{I} T P M A}\right] \rightleftarrows\left[\mathrm{Cu}^{\mathrm{I} T P M A}\right]^{+}+\mathrm{Br}^{-}} \\
{\left[\mathrm{Cu}^{\mathrm{I} T P M A}\right]^{+}+\mathrm{RBr} \rightleftarrows\left[\mathrm{BrCu}^{\mathrm{II}} \mathrm{TPMA}\right]^{+}+\mathrm{R}^{\bullet}}
\end{gathered}
$$

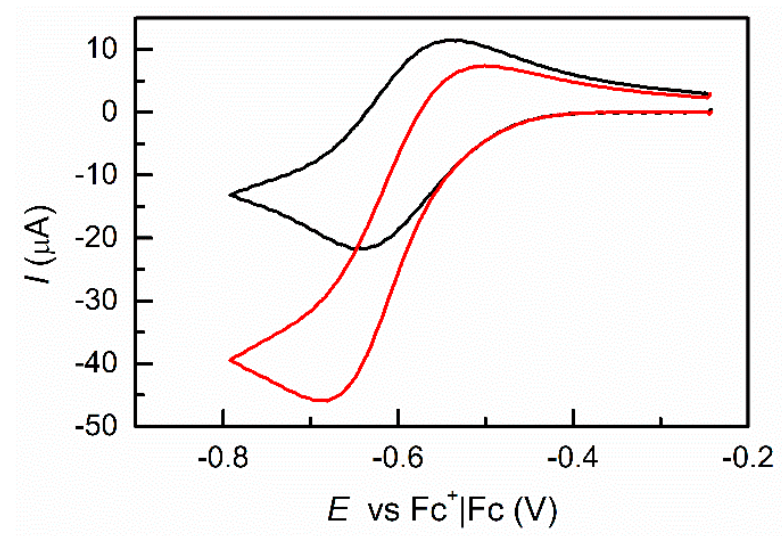

Figure 2. Cyclic voltammetry of $10^{-3} \mathrm{M}\left[\mathrm{BrCu}^{\mathrm{II}} \mathrm{TPMA}\right]^{+}$in DMF/styrene $(50: 50, v / v)+0.1 \mathrm{M}$ $\mathrm{Et}_{4} \mathrm{NBF}_{4}$ in the absence (-) and presence of $1.5 \times 10^{-2} \mathrm{M} \mathrm{EBiB} \mathrm{(-),} \mathrm{recorded} \mathrm{on} \mathrm{a} \mathrm{GC} \mathrm{disk} \mathrm{electrode}$ at $0.2 \mathrm{~V} / \mathrm{s}$ and $\mathrm{T}=80^{\circ} \mathrm{C}$.

\subsubsection{Effect of the Solvent}

Since $e$ ATRP of styrene has never been investigated, the effect of the solvent was first evaluated. The results of a first set of $e$ ATRP experiments are summarized in Table 2. All experiments were performed under potentiostatic control with an applied potential $E_{\text {app }}=E_{1 / 2} \approx E^{\circ}$ of the $\left[\mathrm{BrCu}^{\mathrm{II}} \mathrm{TPMA}\right]^{+} /\left[\mathrm{BrCu}{ }^{\mathrm{I} T P M A}\right]$ couple. First-order kinetic plots and evolution of molecular weight and dispersity in $\mathrm{CH}_{3} \mathrm{CN}$ and DMF are shown in Figure 3, together with an example of typical molecular weight distributions of the obtained PS-Br polymer.

Table 2. Potentiostatic $e$ ATRP of $50 \%(v / v)$ styrene in different solvents at $T=80{ }^{\circ} \mathrm{C}^{1}$.

\begin{tabular}{ccccccccc}
\hline Entry & Solvent & $\begin{array}{c}\boldsymbol{t} \\
(\mathbf{h})\end{array}$ & $\begin{array}{c}\boldsymbol{Q} \\
(\mathbf{C})\end{array}$ & $\begin{array}{c}\text { Conversion } \\
\mathbf{( \% )}\end{array}$ & $\begin{array}{c}\mathbf{1 0}^{\mathbf{2}} \times \boldsymbol{k}_{\mathbf{p}} \mathbf{a p p ~ 2}^{\mathbf{2}} \\
\mathbf{( h}^{-\mathbf{1}} \mathbf{)}\end{array}$ & $\begin{array}{c}\boldsymbol{M}_{\mathbf{n}, \mathbf{t h}}{ }^{3} \\
(\mathbf{k D a})\end{array}$ & $\begin{array}{c}\boldsymbol{M}_{\mathbf{n}} \mathbf{4} \\
(\mathbf{k D a})\end{array}$ & $\boldsymbol{Ð}$ \\
\hline 1 & $\mathrm{DMF}$ & 5 & 5.82 & 34 & 8.7 & 10.5 & 10.6 & 1.26 \\
2 & $\mathrm{DMSO}$ & 2 & 0.99 & 15 & -5 & 4.7 & 4.8 & 1.22 \\
3 & $\mathrm{CH}_{3} \mathrm{CN}$ & 4 & 3.39 & 47 & 17.1 & 14.4 & 17.2 & 1.37 \\
\hline
\end{tabular}

${ }^{1}$ Other conditions: [St]:[EBiB]:[Catalyst] $=435: 1.5: 0.1 ; \mathrm{DP}=291 ;\left[\mathrm{Cu}^{\mathrm{II}}\right]=1 \mathrm{mM} ; E_{\text {app }}=E_{1 / 2} ; V_{\text {tot }}=10 \mathrm{~mL}$; $0.1 \mathrm{M} \mathrm{Et}_{4} \mathrm{NBF}_{4}$ supporting electrolyte. ${ }^{2}$ Apparent rate constant of polymerization, determined as the slope of $\ln \left([\mathrm{St}]_{0} /[\mathrm{St}]\right)$ vs $t .{ }^{3}$ Theoretical molecular weight, calculated as $M_{\mathrm{n}, \mathrm{th}}=M_{\mathrm{EBiB}}+$ conversion $\times \mathrm{DP} \times M_{\mathrm{St}}$. ${ }^{4}$ Determined by GPC. ${ }^{5}$ Not determined because of polymer precipitation.

Although the reaction was well-controlled in all three solvents, significant differences were observed in the overall performance of the process. The polymerization was fastest in $\mathrm{CH}_{3} \mathrm{CN}$, reaching $47 \%$ conversion in $4 \mathrm{~h}$, but the polymer started precipitating at this stage and therefore the reaction had to be stopped. Additionally, dispersity slightly increased with conversion, passing from 1.17 to 1.37 as the conversion increased from $22 \%$ to $47 \%$. Another disadvantage of $\mathrm{CH}_{3} \mathrm{CN}$ is its relatively low boiling point $\left(82{ }^{\circ} \mathrm{C}\right)$, causing some technical issues related to solvent evaporation at the chosen polymerization temperature of $80^{\circ} \mathrm{C}$. The reaction was also fast in DMSO, but even low molecular weight polystyrene is insoluble in this solvent and the process had to be stopped after only $1 \mathrm{~h}$ of polymerization with $15 \%$ conversion when solid PS separated from the reaction mixture. Polymerization 
was slowest in DMF, but the reaction proceeded with good control and did not present solubility issues. GPC traces taken during eATRP in DMF were symmetrical without tailing and continuously shifted to higher molecular weights with increasing conversion (Figure 3c). Therefore, this solvent was chosen for further investigations on eATRP of styrene. The effects of monomer concentration, catalyst loading, and targeted degree of polymerization were examined.
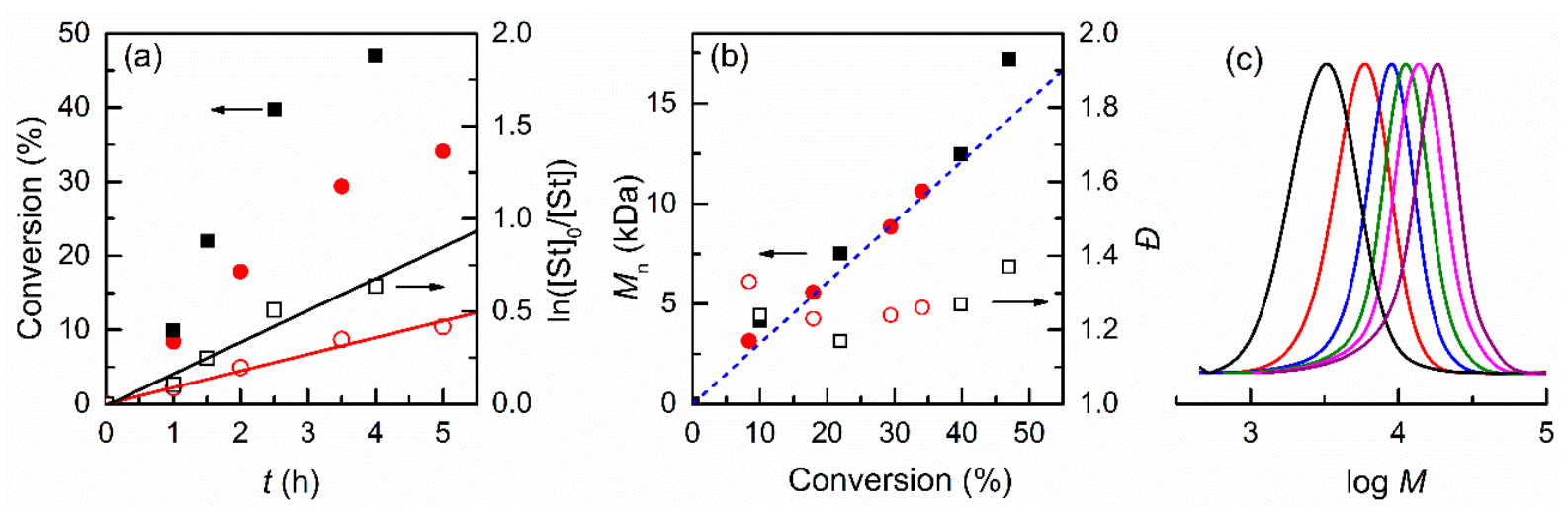

Figure 3. (a) First-order kinetic plots and (b) evolution of $M_{\mathrm{n}}$ and $\boxminus$ with conversion for potentiostatic $e$ ATRP of styrene in DMF (circles) or $\mathrm{CH}_{3} \mathrm{CN}$ (squares), performed at $80^{\circ} \mathrm{C}$ at $E_{\text {app }}=E_{1 / 2}$ with [St]:[EBiB]:[Catalyst] $=435: 1.5: 0.1 ; \mathrm{DP}=291$; $\left[\mathrm{Cu}^{\mathrm{II}}\right]=1 \mathrm{mM}$. The dashed line in $(\mathbf{b})$ represents theoretical molecular weights. (c) Molecular weight distributions of PS-Br produced by eATRP of $50 \%(v / v)$ styrene in DMF.

\subsubsection{Effect of Initiator and Concentrations of Catalyst and Monomer in DMF}

Table 3 shows the results of $e$ ATRP of styrene carried out in DMF at different conditions. The effect of the initiator concentration was first investigated. Keeping constant both monomer and catalyst concentrations, the quantity of $\mathrm{EBiB}$ was lowered from $15 \mathrm{mM}$ down to $2 \mathrm{mM}$, which corresponds to an increase of target degree of polymerization (DP) from 290 to 2175 (Table 3, entries 1-3). In this set of polymerizations, the reaction was stopped when $Ð$ became higher than 1.3. Polymerizations were well-controlled as evidenced by the trends shown in Figure 4, but the overall rate of the reaction decreased as the concentration of the initiator was lowered. This led to a decrease of monomer conversion from $34 \%$ to $6.3 \%$. However, high molecular weight PS could be prepared when high DP was targeted.

Next, the concentration of the catalyst was lowered from $1 \mathrm{mM}$ to $0.2 \mathrm{mM}$ (Table 3, entries 3-7), keeping the initiator concentration at $2 \mathrm{mM}$ to prepare high molecular weight PS. Lowering the catalyst load is important to improve the cleanness of the system and a slight improvement of process performance was observed. Compared to eATRP with $1 \mathrm{mM}$ copper (Table 3, entry 3), monomer conversion after $2 \mathrm{~h}$ increased to $7.7 \%$ and $8.8 \%$ when the catalyst concentration was lowered to $0.5 \mathrm{mM}$ and $0.2 \mathrm{mM}$, respectively. In all cases the dispersity of the obtained polymer was $\sim 1.3$. When the reactions with $0.5 \mathrm{mM}$ and $0.2 \mathrm{mM}$ catalyst were protracted up to $4 \mathrm{~h}$, conversions further increased to $11.4 \%$ and $12.5 \%$ yielding PS with $M_{n}=26.6 \mathrm{kDa}$ and 31.9, respectively. However, in both cases the dispersity worsened reaching 1.46 and 1.52 at $\left[\mathrm{Cu}^{\mathrm{II}}\right]=0.5 \mathrm{mM}$ and $0.2 \mathrm{mM}$, respectively.

Last, a series of $e$ ATRPs with different amounts of monomer $(25 \%, 50 \%$, and $75 \%(v / v))$ was carried out under otherwise identical conditions, i.e., $\left[\mathrm{Cu}^{\mathrm{II}}\right]=1 \mathrm{mM},[\mathrm{EBiB}]=15 \mathrm{mM}$, $T=80{ }^{\circ} \mathrm{C}$ (Table 3, entries 1,8 , and 9). In all monomer/solvent ratios $(1: 3-3: 1, v / v)$ polymerization proceeded in a well-controlled manner as attested by the low values of dispersity and the excellent match between experimental molecular weights and theoretical values (Figure 5). Interestingly, the monomer concentration had a noticeable effect on the polymerization rate. The apparent propagation rate constant, $k_{\mathrm{p}}$ app, increased from $2.4 \times 10^{-2} \mathrm{~h}^{-1}$ to $0.10 \mathrm{~h}^{-1}$ when the initial styrene concentration was changed from $25 \%$ to $75 \%(v / v)$. This suggests that increasing the amount of styrene in the reaction mixture could be an efficient strategy to address the slow polymerization kinetics of the monomer. 
Table 3. Potentiostatic eATRP of styrene in DMF initiated by EBiB at $80^{\circ} \mathrm{C}^{1}$.

\begin{tabular}{|c|c|c|c|c|c|c|c|c|c|c|c|}
\hline Entry & $\begin{array}{c}\text { St } \\
(\mathrm{vol} \%)\end{array}$ & $\begin{array}{l}{\left[\mathrm{Cu}^{\mathrm{II}}\right]} \\
(\mathrm{mM})\end{array}$ & $\begin{array}{c}\text { [EBiB] } \\
(\mathrm{mM})\end{array}$ & DP & $\begin{array}{c}t \\
\text { (h) }\end{array}$ & $\begin{array}{c}Q \\
\text { (C) }\end{array}$ & $\begin{array}{c}\text { Conversion } \\
(\%)\end{array}$ & $\begin{array}{c}10^{2} \times k_{\mathrm{p}}{ }^{\text {app } 2} \\
\left(\mathrm{~h}^{-1}\right)\end{array}$ & $\begin{array}{c}M_{\mathrm{n}, \mathrm{th}}{ }^{3} \\
(\mathrm{kDa})\end{array}$ & $\begin{array}{l}M_{\mathrm{n}}^{4} \\
(\mathrm{kDa})\end{array}$ & $\boxplus$ \\
\hline 1 & 50 & 1.0 & 15 & 290 & 5 & 5.8 & 34 & 8.7 & 10.5 & 10.7 & 1.26 \\
\hline 2 & 50 & 1.0 & 7.5 & 580 & 4 & 7.7 & 11 & 2.9 & 6.7 & 5.6 & 1.33 \\
\hline 3 & 50 & 1.0 & 2 & 2175 & 2 & 2.5 & 6.3 & 3.1 & 14.5 & 14.1 & 1.33 \\
\hline 4 & 50 & 0.5 & 2 & 2175 & 2 & 2.6 & 7.7 & 3.0 & 17.6 & 19.1 & 1.32 \\
\hline 5 & 50 & 0.5 & 2 & 2175 & 4 & 3.5 & 11.4 & 3.0 & 26.0 & 26.6 & 1.46 \\
\hline 6 & 50 & 0.2 & 2 & 2175 & 2 & 1.4 & 8.8 & 3.4 & 20.2 & 24.3 & 1.32 \\
\hline 7 & 50 & 0.2 & 2 & 2175 & 4 & 1.9 & 12.5 & 3.4 & 28.5 & 31.9 & 1.52 \\
\hline 8 & 25 & 1.0 & 15 & 145 & 5 & 3.1 & 13 & 2.4 & 2.1 & 2.3 & 1.35 \\
\hline 9 & 75 & 1.0 & 15 & 435 & 5 & 10.1 & 40 & 10.0 & 18.3 & 19.4 & 1.29 \\
\hline
\end{tabular}

${ }^{1}$ Other conditions: $E_{\text {app }}=E_{1 / 2} ; V_{\text {tot }}=10 \mathrm{~mL}$; supporting electrolyte $\left(\mathrm{Et}_{4} \mathrm{NBF}_{4}\right): 0.1 \mathrm{M}$ (entries 1 and 2 ) or $0.2 \mathrm{M}$ (entry 3 ). ${ }^{2}$ Apparent rate constant of polymerization, determined as the slope of $\ln \left([\mathrm{St}]_{0} /[\mathrm{St}]\right)$ vs $t .{ }^{3}$ Theoretical molecular weight, calculated as $M_{\mathrm{n}, \mathrm{th}}=M_{\mathrm{EBiB}}+$ conversion $\times \mathrm{DP} \times \mathrm{M}_{\mathrm{St} .}{ }^{4}$ Determined by GPC.
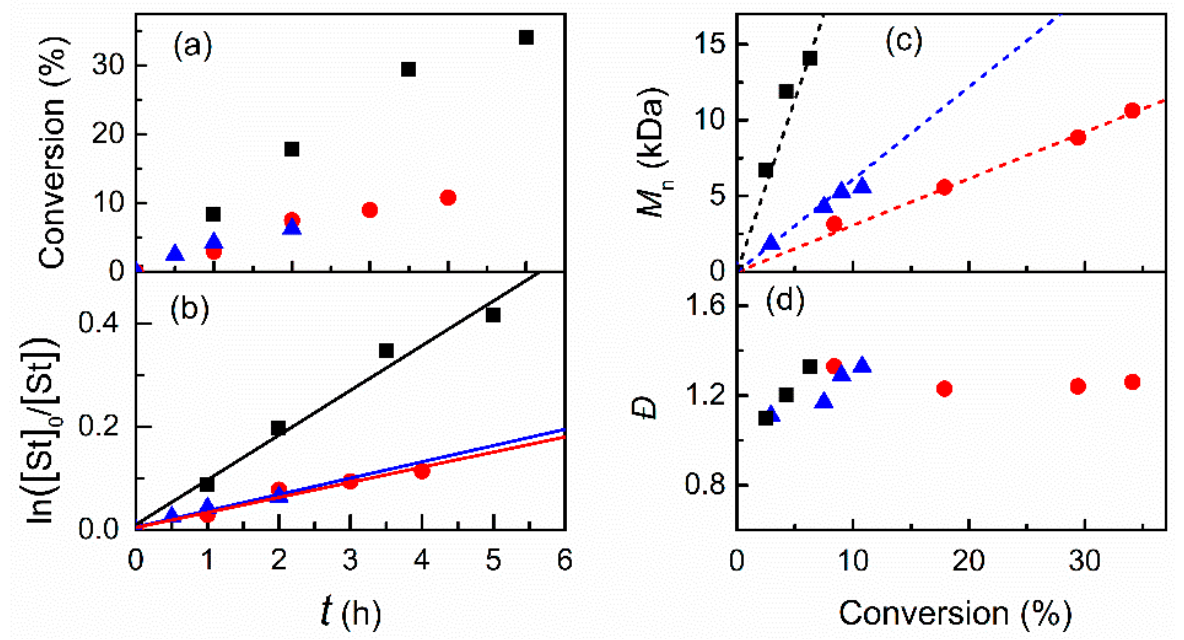

Figure 4. (a) Conversion, (b) kinetic plots and evolution of (c) $M_{\mathrm{n}}$ and (d) $Đ$ with conversion for potentiostatic $e$ ATRP of $50 \%(v / v)$ styrene in DMF at $E_{\text {app }}=E_{1 / 2}$. For reaction conditions refer to Table 3, entry: $1(\boldsymbol{\square}), 2(\bullet)$ and $3(\boldsymbol{\Delta})$ and. The dashed lines in (c) represent the theoretical molecular weight.
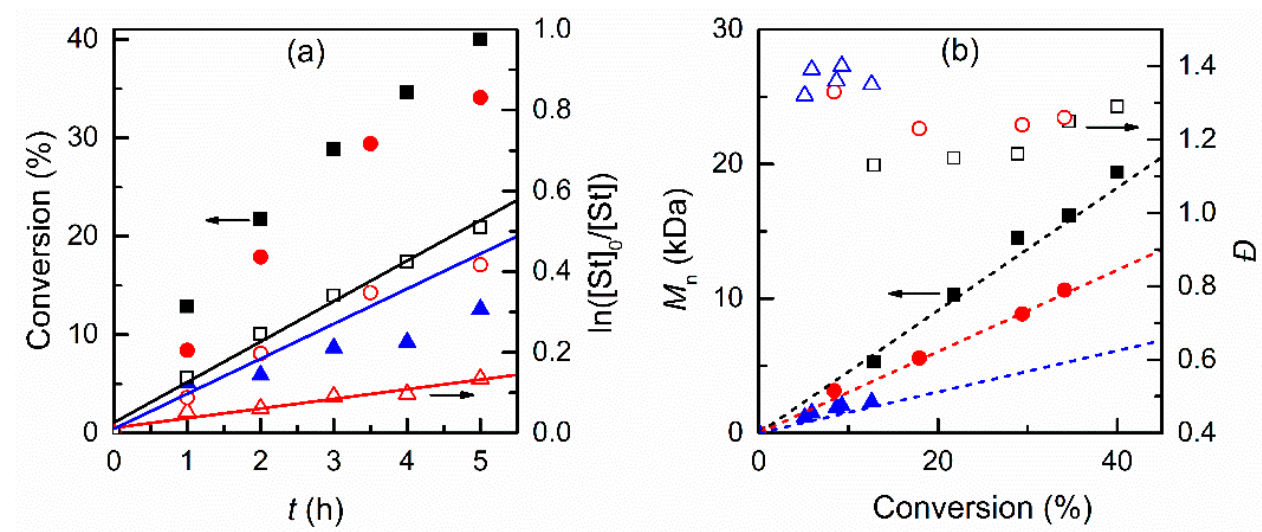

Figure 5. (a) Kinetic plots and (b) evolution of $M_{\mathrm{n}}$ and $\emptyset$ with conversion for potentiostatic $e$ ATRP of styrene in DMF at St/DMF $(v / v)=75 / 25$ (squares), 50/50 (circles) and 25/75 (triangles); other conditions: $[\mathrm{St}]:[\mathrm{EBiB}]:[$ Catalyst $]=x: 1.5: 0.1$, where $x=654,435$, and $218 ;\left[\mathrm{Cu}^{\mathrm{II}}\right]=10^{-3} \mathrm{M} ; E_{\mathrm{app}}=E_{1 / 2}$; $T=80^{\circ} \mathrm{C}$. The dashed lines in $(\mathbf{b})$ represent the theoretical molecular weights. 
The effect of monomer concentration on the polymerization rate is more marked by passing from 25 to $50 \%$ than from 50 to $75 \%(v / v)$. First-order kinetics and linear evolution of $M_{n}$ with conversion were observed in all cases. Dispersity, however, was slightly better when polymerization was carried out above $25 \%(v / v)$ styrene. In terms of polymer molecular weight, the best results were obtained when styrene was polymerized at $75 \%$ $(v / v)$ monomer, albeit the use of excess supporting electrolyte to improve the conductivity of the mixture. Therefore, polymerizing at $75 \%(v / v)$ styrene produces more polymer per batch, amortizing the cost of the expensive electrolyte.

\subsection{Temporal Control of Polymerization}

Temporal control in eATRP can be easily achieved by appropriately adjusting the applied potential, $E_{\mathrm{app}}$, so that polymerization can be triggered, stopped, and then restarted when desired $[19,58]$. The electrochemical switch can be designed in two different ways: (i) intermittent switching between two $E_{\text {app }}$ values, one for electrochemical (re)generation of the activator and the other for its rapid oxidation, and (ii) a fixed $E_{\text {app }}$ value appropriate for activator (re)generation with toggling of the electrochemical cell between ON and OFF positions. The first approach has been widely tested showing that virtually no polymerization occurs during the OFF period because all $\mathrm{Cu}^{\mathrm{I}}$ species in the solution are rapidly oxidized to $\mathrm{Cu}^{\mathrm{II}}$. We focused on the second approach, which has never been tested although it is conceptually simpler than the first. eATRP of 75\% $(v / v)$ styrene in DMF (Table 3, entry 9) was repeated by applying $E_{\mathrm{app}}=E_{1 / 2}$ for three 1 -h steps interposed by two 1-h steps in which the cell was switched off. As shown in Figure 6a, during the periods of catalyst activation by electroreduction, 7-11\% monomer conversion could be achieved, whereas further increase of conversion was $<1 \%$ during $1 \mathrm{~h}$ when the cell was switched off. Polymerization was always well-controlled producing a polymer with very narrow molecular weight distribution (Figure $6 \mathrm{~b}$ ). Additionally, $M_{\mathrm{n}}$ increased linearly with conversion, closely matching the theoretical values, each time the polymerization was triggered after a period of almost inactivity in which there was no applied potential, clearly indicating a good chain-end fidelity. Interestingly, temporal control in eATRP works very well without toggling between two values of $E_{\mathrm{app}}$ as is usually done. When the cell was switched off, the reaction continued at a very reduced rate with $<1 \%$ monomer conversion in $1 \mathrm{~h}$ as compared to $7-11 \%$ obtained when current was circulated in the cell. This points out that the effective concentration of $\mathrm{Cu}^{\mathrm{I}}$ in solution during eATRP is quite low and when the continuous regeneration is stopped, the polymerization rate drops rapidly and eventually the reaction stops.

(a)

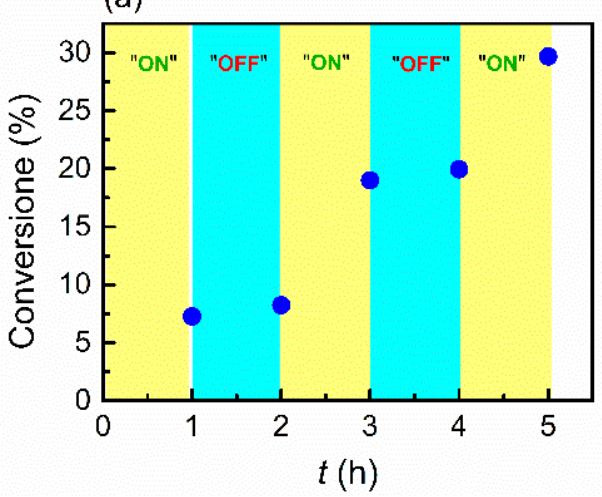

(b)

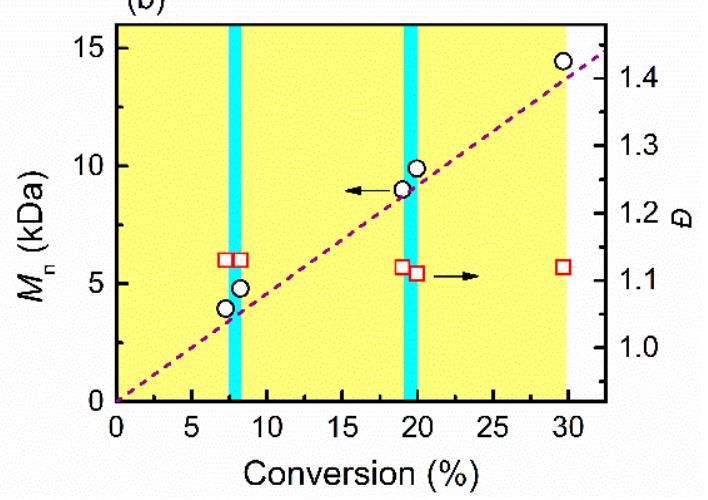

Figure 6. (a) Kinetic plots and (b) evolution of $M_{\mathrm{n}}$ and $Đ$ with conversion for potentiostatic $e$ ATRP of $75 \%(v / v)$ styrene in DMF at $E_{\text {app }}=E_{1 / 2}$. Conditions: [St]:[EBiB]:[Catalyst] = 654:1.5:0.1; $\left[\mathrm{Cu}^{\mathrm{II}}\right]=10^{-3} \mathrm{M}$. The dashed line represents the theoretical molecular weight. 


\subsection{Electrochemical Chain Extension}

The livingness of the polymerization was demonstrated also by chain extension from a PS-Br macroinitiator. To this end, $e$ ATRP of $75 \%(v / v)$ styrene in DMF was carried at $E_{\text {app }}=E_{1 / 2}$ for $2 \mathrm{~h}$ to prepare a PS-Br macroinitiator with $M_{\mathrm{n}}=10.9 \mathrm{kDa}$ and $Ð=1.14$ (see materials and methods). After isolation and purification, the polymer was used as a macroinitiator in a second $e$ ATRP experiment conducted in $75 \%(v / v)$ styrene in DMF at $E_{\text {app }}=E_{1 / 2}$. A clear shift of the molecular weight distribution was observed after the extension experiment (Figure 7). The GPC trace remained monomodal showing no dead chains in the macroinitiator or during the chain extension.

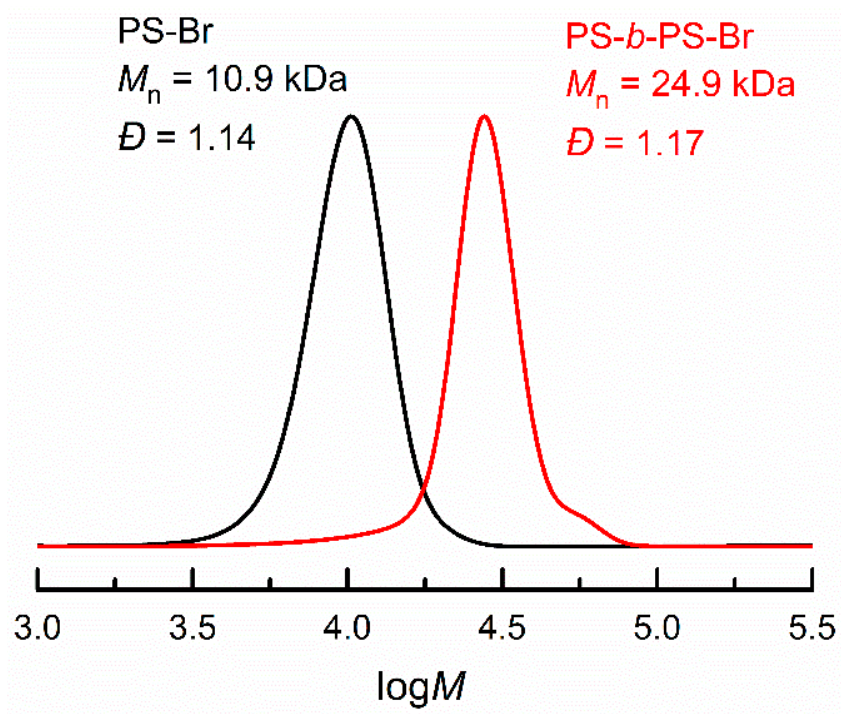

Figure 7. Molecular weight distributions of PS-Br macroinitiator (-) and PS-b-PS-Br homopolymer (-) after chain extension by eATRP of $75 \%(v / v)$ styrene in DMF at $T=80{ }^{\circ} \mathrm{C}$ and $E_{\mathrm{app}}=E_{1 / 2}$.

\section{Conclusions}

Electrochemically mediated ATRP of styrene was studied in detail by varying a series of parameters such as monomer amount, solvent, degree of polymerization, and catalyst concentration. DMF was the best solvent among the three polar solvents chosen for this study, namely DMF, DMSO, and $\mathrm{CH}_{3} \mathrm{CN}$. We determined that best polymerizations take place when the monomer amount is beyond $50 \%(v / v)$ at $T=80^{\circ} \mathrm{C}$ in DMF. The livingness of the polymerization was verified via chain extension from PS-Br macroinitiator, with styrene, affording a controlled PS- $b$-PS-Br linear homopolymer. Livingness was also confirmed by excellent temporal control of polymerization, achieved by toggling between active $e$ ATRP via $E_{\text {app }}=E_{1 / 2}$ and interruption of current passage to stop the reaction. This study shows that $e$ ATRP of styrene at $80^{\circ} \mathrm{C}$ is a well-controlled process, but monomer conversion is limited because of the slow propagation rate of styrene. The electrochemical method is, however, appropriate for the preparation of medium molecular weight polymers in few hours at a moderate temperature.

Author Contributions: Conceptualization, A.A.I. and F.D.B.; methodology, A.A.I. and F.D.B.; investigation, G.M.C., E.T., and F.D.B.; supervision: A.A.I. and F.D.B.; data curation: all authors; writing - original draft preparation, A.A.I. and F.D.B.; writing—review and editing, A.A.I. and F.D.B. All authors have read and agreed to the published version of the manuscript.

Funding: This research received no external funding.

Institutional Review Board Statement: Not applicable.

Informed Consent Statement: Not applicable.

Data Availability Statement: All data collected in this study are contained within the article. 
Acknowledgments: F.D.B acknowledges sponsoring by national funds through FCT—Fundação para Ciência e Tecnologia-under the project UIDB/00285/2020.

Conflicts of Interest: The authors declare no conflict of interest.

\section{References}

1. Matyjaszewski, K. Atom Transfer Radical Polymerization (ATRP): Current Status and Future Perspectives. Macromolecules 2012, 45, 4015-4039. [CrossRef]

2. Matyjaszewski, K.; Gao, H.; Sumerlin, B.S.; Tsarevsky, N.V. (Eds.) Reversible Deactivation Radical Polymerization: Materials and Applications; ACS Symposium Series; American Chemical Society: Washington, DC, USA, 2018; Volume 1285, ISBN 9780841233232.

3. Matyjaszewski, K.; Jakubowski, W.; Min, K.; Tang, W.; Huang, J.; Braunecker, W.A.; Tsarevsky, N.V. Diminishing Catalyst Concentration in Atom Transfer Radical Polymerization with Reducing Agents. Proc. Natl. Acad. Sci. USA 2006, 103, 15309-15314. [CrossRef] [PubMed]

4. Konkolewicz, D.; Magenau, A.J.D.; Averick, S.E.; Simakova, A.; He, H.; Matyjaszewski, K. ICAR ATRP with Ppm Cu Catalyst in Water. Macromolecules 2012, 45, 4461-4468. [CrossRef]

5. Min, K.; Gao, H.; Matyjaszewski, K. Use of Ascorbic Acid as Reducing Agent for Synthesis of Well-Defined Polymers by ARGET ATRP. Macromolecules 2007, 40, 1789-1791. [CrossRef]

6. Chan, N.; Cunningham, M.F.; Hutchinson, R.A. ARGET ATRP of Methacrylates and Acrylates with Stoichiometric Ratios of Ligand to Copper. Macromol. Chem. Phys. 2008, 209, 1797-1805. [CrossRef]

7. Simakova, A.; Averick, S.E.; Konkolewicz, D.; Matyjaszewski, K. Aqueous ARGET ATRP. Macromolecules 2012, 45, 6371-6379. [CrossRef]

8. Mendonça, P.V.; Ribeiro, J.P.M.; Abreu, C.M.R.; Guliashvili, T.; Serra, A.C.; Coelho, J.F.J. Thiourea Dioxide As a Green and Affordable Reducing Agent for the ARGET ATRP of Acrylates, Methacrylates, Styrene, Acrylonitrile, and Vinyl Chloride. ACS Macro Lett. 2019, 8, 315-319. [CrossRef]

9. Abreu, C.M.R.; Serra, A.C.; Popov, A.V.; Matyjaszewski, K.; Guliashvili, T.; Coelho, J.F.J. Ambient Temperature Rapid SARA ATRP of Acrylates and Methacrylates in Alcohol-Water Solutions Mediated by a Mixed Sulfite/Cu(II)Br $\mathrm{Br}_{2}$ Catalytic System. Polym. Chem. 2013, 4, 5629. [CrossRef]

10. Mendes, J.P.; Branco, F.; Abreu, C.M.R.; Mendonça, P.V.; Serra, A.C.; Popov, A.V.; Guliashvili, T.; Coelho, J.F.J. Sulfolane: An Efficient and Universal Solvent for Copper-Mediated Atom Transfer Radical (Co)Polymerization of Acrylates, Methacrylates, Styrene, and Vinyl Chloride. ACS Macro Lett. 2014, 3, 858-861. [CrossRef]

11. Lorandi, F.; Fantin, M.; Isse, A.A.; Gennaro, A. RDRP in the Presence of $\mathrm{Cu}^{0}$ : The Fate of $\mathrm{Cu}(\mathrm{I})$ Proves the Inconsistency of SET-LRP Mechanism. Polymer 2015, 72, 238-245. [CrossRef]

12. Kopeć, M.; Yuan, R.; Gottlieb, E.; Abreu, C.M.R.; Song, Y.; Wang, Z.; Coelho, J.F.J.; Matyjaszewski, K.; Kowalewski, T. Polyacrylonitrile- b -Poly(Butyl Acrylate) Block Copolymers as Precursors to Mesoporous Nitrogen-Doped Carbons: Synthesis and Nanostructure. Macromolecules 2017, 50, 2759-2767. [CrossRef]

13. Tasdelen, M.A.; Uygun, M.; Yagci, Y. Photoinduced Controlled Radical Polymerization. Macromol. Rapid Commun. 2011, 32, 58-62. [CrossRef] [PubMed]

14. Konkolewicz, D.; Schröder, K.; Buback, J.; Bernhard, S.; Matyjaszewski, K. Visible Light and Sunlight Photoinduced ATRP with Ppm of Cu Catalyst. ACS Macro Lett. 2012, 1, 1219-1223. [CrossRef]

15. Anastasaki, A.; Nikolaou, V.; Zhang, Q.; Burns, J.; Samanta, S.R.; Waldron, C.; Haddleton, A.J.; McHale, R.; Fox, D.; Percec, V.; et al. Copper(II)/Tertiary Amine Synergy in Photoinduced Living Radical Polymerization: Accelerated Synthesis of $\omega$-Functional and $\alpha, \omega$-Heterofunctional Poly(Acrylates). J. Am. Chem. Soc. 2014, 136, 1141-1149. [CrossRef]

16. Treat, N.J.; Sprafke, H.; Kramer, J.W.; Clark, P.G.; Barton, B.E.; Read de Alaniz, J.; Fors, B.P.; Hawker, C.J. Metal-Free Atom Transfer Radical Polymerization. J. Am. Chem. Soc. 2014, 136, 16096-16101. [CrossRef]

17. Yilmaz, G.; Yagci, Y. Photoinduced Metal-Free Atom Transfer Radical Polymerizations: State-of-the-Art, Mechanistic Aspects and Applications. Polym. Chem. 2018, 9, 1757-1762. [CrossRef]

18. Pan, X.; Fang, C.; Fantin, M.; Malhotra, N.; So, W.Y.; Peteanu, L.A.; Isse, A.A.; Gennaro, A.; Liu, P.; Matyjaszewski, K. Mechanism of Photoinduced Metal-Free Atom Transfer Radical Polymerization: Experimental and Computational Studies. J. Am. Chem. Soc. 2016, 138, 2411-2425. [CrossRef] [PubMed]

19. Magenau, A.J.D.; Strandwitz, N.C.; Gennaro, A.; Matyjaszewski, K. Electrochemically Mediated Atom Transfer Radical Polymerization. Science 2011, 332, 81-84. [CrossRef]

20. Magenau, A.J.D.; Bortolamei, N.; Frick, E.; Park, S.; Gennaro, A.; Matyjaszewski, K. Investigation of Electrochemically Mediated Atom Transfer Radical Polymerization. Macromolecules 2013, 46, 4346-4353. [CrossRef]

21. Lorandi, F.; Fantin, M.; Isse, A.A.; Gennaro, A. Electrochemically Mediated Atom Transfer Radical Polymerization of N-Butyl Acrylate on Non-Platinum Cathodes. Polym. Chem. 2016, 7, 5357-5365. [CrossRef]

22. Fantin, M.; Lorandi, F.; Isse, A.A.; Gennaro, A. Sustainable Electrochemically-Mediated Atom Transfer Radical Polymerization with Inexpensive Non-Platinum Electrodes. Macromol. Rapid Commun. 2016, 37, 1318-1322. [CrossRef] [PubMed]

23. Chmielarz, P.; Fantin, M.; Park, S.; Isse, A.A.; Gennaro, A.; Magenau, A.J.D.; Sobkowiak, A.; Matyjaszewski, K. Electrochemically Mediated Atom Transfer Radical Polymerization (eATRP). Prog. Polym. Sci. 2017, 69, 47-78. [CrossRef] 
24. Lorandi, F.; Fantin, M.; Isse, A.A.; Gennaro, A. Electrochemical Triggering and Control of Atom Transfer Radical Polymerization. Curr. Opin. Electrochem. 2018, 8, 1-7. [CrossRef]

25. Mohapatra, H.; Kleiman, M.; Esser-Kahn, A.P. Mechanically Controlled Radical Polymerization Initiated by Ultrasound. Nat. Chem. 2017, 9, 135-139. [CrossRef]

26. Wang, Z.; Pan, X.; Li, L.; Fantin, M.; Yan, J.; Wang, Z.; Wang, Z.; Xia, H.; Matyjaszewski, K. Enhancing Mechanically Induced ATRP by Promoting Interfacial Electron Transfer from Piezoelectric Nanoparticles to Cu Catalysts. Macromolecules 2017, 50, 7940-7948. [CrossRef]

27. Zaborniak, I.; Chmielarz, P. Ultrasound-Mediated Atom Transfer Radical Polymerization (ATRP). Materials 2019, 12, 3600. [CrossRef]

28. Pan, X.; Fantin, M.; Yuan, F.; Matyjaszewski, K. Externally Controlled Atom Transfer Radical Polymerization. Chem. Soc. Rev. 2018, 47, 5457-5490. [CrossRef]

29. Ribelli, T.G.; Lorandi, F.; Fantin, M.; Matyjaszewski, K. Atom Transfer Radical Polymerization: Billion Times More Active Catalysts and New Initiation Systems. Macromol. Rapid Commun. 2019, 40, 1800616. [CrossRef]

30. De Paoli, P.; Isse, A.A.; Bortolamei, N.; Gennaro, A. New Insights into the Mechanism of Activation of Atom Transfer Radical Polymerization by Cu(I) Complexes. Chem. Commun. 2011, 47, 3580-3582. [CrossRef] [PubMed]

31. Isse, A.A.; Bortolamei, N.; De Paoli, P.; Gennaro, A. On the Mechanism of Activation of Copper-Catalyzed Atom Transfer Radical Polymerization. Electrochim. Acta 2013, 110, 655-662. [CrossRef]

32. Fantin, M.; Lorandi, F.; Gennaro, A.; Isse, A.; Matyjaszewski, K. Electron Transfer Reactions in Atom Transfer Radical Polymerization. Synthesis 2017, 49, 3311-3322. [CrossRef]

33. Penczek, S.; Pretula, J.; Lewiński, P. Dormant Polymers and Their Role in Living and Controlled Polymerizations; Influence on Polymer Chemistry, Particularly on the Ring Opening Polymerization. Polymers 2017, 9, 646. [CrossRef]

34. Tang, W.; Kwak, Y.; Braunecker, W.; Tsarevsky, N.V.; Coote, M.L.; Matyjaszewski, K. Understanding Atom Transfer Radical Polymerization: Effect of Ligand and Initiator Structures on the Equilibrium Constants. J. Am. Chem. Soc. 2008, 130, 10702-10713. [CrossRef] [PubMed]

35. Braunecker, W.A.; Tsarevsky, N.V.; Gennaro, A.; Matyjaszewski, K. Thermodynamic Components of the Atom Transfer Radical Polymerization Equilibrium: Quantifying Solvent Effects. Macromolecules 2009, 42, 6348-6360. [CrossRef]

36. Buback, M.; Morick, J. Equilibrium Constants and Activation Rate Coefficients for Atom Transfer Radical Polymerizations at Pressures up to 2500 Bar. Macromol. Chem. Phys. 2010, 211, 2154-2161. [CrossRef]

37. Wang, Y.; Kwak, Y.; Buback, J.; Buback, M.; Matyjaszewski, K. Determination of ATRP Equilibrium Constants under Polymerization Conditions. ACS Macro Lett. 2012, 1, 1367-1370. [CrossRef]

38. Lorandi, F.; Fantin, M.; Isse, A.A.; Gennaro, A.; Matyjaszewski, K. New Protocol to Determine the Equilibrium Constant of Atom Transfer Radical Polymerization. Electrochim. Acta 2018, 260, 648-655. [CrossRef]

39. De Bon, F.; Isse, A.A.; Gennaro, A. Electrochemically Mediated Atom Transfer Radical Polymerization of Methyl Methacrylate: The Importance of Catalytic Halogen Exchange. Chem. Electro. Chem. 2019, 6, 4257-4265. [CrossRef]

40. Chmielarz, P.; Sobkowiak, A.; Matyjaszewski, K. A Simplified Electrochemically Mediated ATRP Synthesis of PEO-b-PMMA Copolymers. Polymer 2015, 77, 266-271. [CrossRef]

41. Chmielarz, P.; Yan, J.; Krys, P.; Wang, Y.; Wang, Z.; Bockstaller, M.R.; Matyjaszewski, K. Synthesis of Nanoparticle Copolymer Brushes via Surface-Initiated seATRP. Macromolecules 2017, 50, 4151-4159. [CrossRef]

42. Wang, J.; Tian, M.; Li, S.; Wang, R.; Du, F.; Xue, Z. Ligand-Free Iron-Based Electrochemically Mediated Atom Transfer Radical Polymerization of Methyl Methacrylate. Polym. Chem. 2018, 9, 4386-4394. [CrossRef]

43. De Bon, F.; Ribeiro, D.C.M.; Abreu, C.M.R.; Rebelo, R.A.C.; Isse, A.A.; Serra, A.C.; Gennaro, A.; Matyjaszewski, K.; Coelho, J.F.J. Under Pressure: Electrochemically-Mediated Atom Transfer Radical Polymerization of Vinyl Chloride. Polym. Chem. 2020, 11, 6745-6762. [CrossRef]

44. Guo, J.-K.; Zhou, Y.-N.; Luo, Z.-H. Iron-Based Electrochemically Mediated Atom Transfer Radical Polymerization with Tunable Catalytic Activity. AIChE J. 2018, 64, 961-969. [CrossRef]

45. De Bon, F.; Isse, A.A.; Gennaro, A. Towards Scale-up of Electrochemically-Mediated Atom Transfer Radical Polymerization: Use of a Stainless-Steel Reactor as Both Cathode and Reaction Vessel. Electrochim. Acta 2019, 304, 505-512. [CrossRef]

46. Zaborniak, I.; Chmielarz, P.; Martinez, M.R.; Wolski, K.; Wang, Z.; Matyjaszewski, K. Synthesis of High Molecular Weight Poly(n-Butyl Acrylate) Macromolecules via seATRP: From Polymer Stars to Molecular Bottlebrushes. Eur. Polym. J. 2020 126, 109566. [CrossRef]

47. Chmielarz, P.; Park, S.; Simakova, A.; Matyjaszewski, K. Electrochemically Mediated ATRP of Acrylamides in Water. Polymer 2015, 60, 302-307. [CrossRef]

48. Fantin, M.; Isse, A.A.; Gennaro, A.; Matyjaszewski, K. Understanding the Fundamentals of Aqueous ATRP and Defining Conditions for Better Control. Macromolecules 2015, 48, 6862-6875. [CrossRef]

49. Strover, L.T.; Malmström, J.; Stubbing, L.A.; Brimble, M.A.; Travas-Sejdic, J. Electrochemically-Controlled Grafting of Hydrophilic Brushes from Conducting Polymer Substrates. Electrochim. Acta 2016, 188, 57-70. [CrossRef]

50. Sun, Y.; Lathwal, S.; Wang, Y.; Fu, L.; Olszewski, M.; Fantin, M.; Enciso, A.E.; Szczepaniak, G.; Das, S.; Matyjaszewski, K. Preparation of Well-Defined Polymers and DNA-Polymer Bioconjugates via Small-Volume EATRP in the Presence of Air. ACS Macro Lett. 2019, 8, 603-609. [CrossRef] 
51. Michieletto, A.; Lorandi, F.; De Bon, F.; Isse, A.A.; Gennaro, A. Biocompatible Polymers via Aqueous Electrochemically Mediated Atom Transfer Radical Polymerization. J. Polym. Sci. 2020, 58, 114-123. [CrossRef]

52. Lorandi, F.; Fantin, M.; Wang, Y.; Isse, A.A.; Gennaro, A.; Matyjaszewski, K. Atom Transfer Radical Polymerization of Acrylic and Methacrylic Acids: Preparation of Acidic Polymers with Various Architectures. ACS Macro Lett. 2020, 9, 693-699. [CrossRef]

53. Zaborniak, I.; Chmielarz, P.; Matyjaszewski, K. Synthesis of Riboflavin-Based Macromolecules through Low Ppm ATRP in Aqueous Media. Macromol. Chem. Phys. 2020, 221, 1900496. [CrossRef]

54. De Bon, F.; Marenzi, S.; Isse, A.A.; Durante, C.; Gennaro, A. Electrochemically Mediated Aqueous Atom Transfer Radical Polymerization of N,N-Dimethylacrylamide. ChemElectroChem 2020, 7, 1378-1388. [CrossRef]

55. Fantin, M.; Park, S.; Wang, Y.; Matyjaszewski, K. Electrochemical Atom Transfer Radical Polymerization in Miniemulsion with a Dual Catalytic System. Macromolecules 2016, 49, 8838-8847. [CrossRef]

56. Fantin, M.; Chmielarz, P.; Wang, Y.; Lorandi, F.; Isse, A.A.; Gennaro, A.; Matyjaszewski, K. Harnessing the Interaction between Surfactant and Hydrophilic Catalyst To Control eATRP in Miniemulsion. Macromolecules 2017, 50, 3726-3732. [CrossRef] [PubMed]

57. Zaborniak, I.; Chmielarz, P. Miniemulsion Switchable Electrolysis under Constant Current Conditions. Polym. Adv. Technol. 2020, 31, 2806-2815. [CrossRef]

58. De Bon, F.; Fantin, M.; Isse, A.A.; Gennaro, A. Electrochemically Mediated ATRP in Ionic Liquids: Controlled Polymerization of Methyl Acrylate in [BMIm][OTf]. Polym. Chem. 2018, 9, 646-655. [CrossRef]

59. Guo, J.K.; Zhou, Y.N.; Luo, Z.H. Electrochemically Mediated ATRP Process Intensified by Ionic Liquid: A “Flash" Polymerization of Methyl Acrylate. Chem. Eng. J. 2019, 372, 163-170. [CrossRef]

60. Wang, J.-S.; Matyjaszewski, K. Controlled/"Living" Radical Polymerization. Halogen Atom Transfer Radical Polymerization Promoted by a Cu(I)/Cu(II) Redox Process. Macromolecules 1995, 28, 7901-7910. [CrossRef]

61. Matyjaszewski, K.; Patten, T.E.; Xia, J. Controlled/“Living” Radical Polymerization. Kinetics of the Homogeneous Atom Transfer Radical Polymerization of Styrene. J. Am. Chem. Soc. 1997, 119, 674-680. [CrossRef]

62. Angot, S.; Murthy, K.S.; Taton, D.; Gnanou, Y. Atom Transfer Radical Polymerization of Styrene Using a Novel Octafunctional Initiator: Synthesis of Well-Defined Polystyrene Stars. Macromolecules 1998, 31, 7218-7225. [CrossRef]

63. Plichta, A.; Li, W.; Matyjaszewski, K. ICAR ATRP of Styrene and Methyl Methacrylate with $\mathrm{Ru}\left(\mathrm{Cp} \mathrm{P}^{*}\right) \mathrm{Cl}(\mathrm{PPh} 3) 2 . \mathrm{Macromolecules}$ 2009, 42, 2330-2332. [CrossRef]

64. Zhang, L.; Miao, J.; Cheng, Z.; Zhu, X. Iron-Mediated ICAR ATRP of Styrene and Methyl Methacrylate in the Absence of Thermal Radical Initiator. Macromol. Rapid Commun. 2010, 31, 275-280. [CrossRef] [PubMed]

65. Mukumoto, K.; Wang, Y.; Matyjaszewski, K. Iron-Based ICAR ATRP of Styrene with Ppm Amounts of Fe III Br 3 and 1,1'Azobis(Cyclohexanecarbonitrile). ACS Macro Lett. 2012, 1, 599-602. [CrossRef]

66. Jakubowski, W.; Matyjaszewski, K. Activator Generated by Electron Transfer for Atom Transfer Radical Polymerization. Macromolecules 2005, 38, 4139-4146. [CrossRef]

67. Jakubowski, W.; Min, K.; Matyjaszewski, K. Activators Regenerated by Electron Transfer for Atom Transfer Radical Polymerization of Styrene. Macromolecules 2006, 39, 39-45. [CrossRef]

68. Jakubowski, W.; Kirci-Denizli, B.; Gil, R.R.; Matyjaszewski, K. Polystyrene with Improved Chain-End Functionality and Higher Molecular Weight by ARGET ATRP. Macromol. Chem. Phys. 2008, 209, 32-39. [CrossRef]

69. Braidi, N.; Buffagni, M.; Ghelfi, F.; Imperato, M.; Menabue, A.; Parenti, F.; Gennaro, A.; Isse, A.A.; Bedogni, E.; Bonifaci, L.; et al. Copper-Catalysed "Activators Regenerated by Electron Transfer" "Atom Transfer Radical Polymerisation" of Styrene from a Bifunctional Initiator in Ethyl Acetate/Ethanol, Using Ascorbic Acid/Sodium Carbonate as Reducing System. Macromol. Res. 2020, 28, 751-761. [CrossRef]

70. Braidi, N.; Buffagni, M.; Buzzoni, V.; Ghelfi, F.; Parenti, F.; Focarete, M.L.; Gualandi, C.; Bedogni, E.; Bonifaci, L.; Cavalca, G.; et al. Unusual Cross-Linked Polystyrene by Copper-Catalyzed ARGET ATRP Using a Bifunctional Initiator and No Cross-Linking Agent. Macromol. Res. 2021, 29, 280-288. [CrossRef]

71. Hsiao, C.-Y.; Han, H.-A.; Lee, G.-H.; Peng, C.-H. AGET and SARA ATRP of Styrene and Methyl Methacrylate Mediated by Pyridyl-Imine Based Copper Complexes. Eur. Polym. J. 2014, 51, 12-20. [CrossRef]

72. Mendes, J.P.; Góis, J.R.; Costa, J.R.C.; Maximiano, P.; Serra, A.C.; Guliashvili, T.; Coelho, J.F.J. Ambient Temperature SARAATRP for Meth(Acrylates), Styrene, and Vinyl Chloride Using Sulfolane/1-Butyl-3-Methylimidazolium Hexafluorophosphate-Based Mixtures. J. Polym. Sci. Part A Polym. Chem. 2017, 55, 1322-1328. [CrossRef]

73. Chmielarz, P.; Krol, P. PSt-b-PU-b-PSt Copolymers Using Tetraphenylethane-Urethane Macroinitiator through SARA ATRP. Express Polym. Lett. 2016, 10, 302-310. [CrossRef]

74. Whitfield, R.; Anastasaki, A.; Nikolaou, V.; Jones, G.R.; Engelis, N.G.; Discekici, E.H.; Fleischmann, C.; Willenbacher, J.; Hawker, C.J.; Haddleton, D.M. Universal Conditions for the Controlled Polymerization of Acrylates, Methacrylates, and Styrene via Cu(0)-RDRP. J. Am. Chem. Soc. 2017, 139, 1003-1010. [CrossRef] [PubMed]

75. Liu, X.; Zhang, L.; Cheng, Z.; Zhu, X. Metal-Free Photoinduced Electron Transfer-Atom Transfer Radical Polymerization (PET-ATRP) via a Visible Light Organic Photocatalyst. Polym. Chem. 2016, 7, 689-700. [CrossRef]

76. Kütahya, C.; Schmitz, C.; Strehmel, V.; Yagci, Y.; Strehmel, B. Near-Infrared Sensitized Photoinduced Atom-Transfer Radical Polymerization (ATRP) with a Copper(II) Catalyst Concentration in the Ppm Range. Angew. Chemie Int. Ed. 2018, 57, 7898-7902. [CrossRef] [PubMed] 
77. Su, C.; Wu, Z.; Lin, C.; Han, H.; Chen, Y.; Chou, P.; Fu, X.; Peng, C. Polystyrene with Persistently Enhanced Fluorescence: Photo-Induced Atom Transfer Radical Polymerization Using a Pyrene-Based Initiator. Chem. Photo. Chem. 2019, 3, $1153-1161$. [CrossRef]

78. Bonometti, V.; Labbé, E.; Buriez, O.; Mussini, P.; Amatore, C. Exploring the First Steps of an Electrochemically-Triggered Controlled Polymerization Sequence: Activation of Alkyl- and Benzyl Halide Initiators by an Electrogenerated FeIISalen Complex. J. Electroanal. Chem. 2009, 633, 99-105. [CrossRef]

79. Buback, M.; Gilbert, R.G.; Hutchinson, R.A.; Klumperman, B.; Kuchta, F.-D.; Manders, B.G.; O’Driscoll, K.F.; Russell, G.T.; Schweer, J. Critically Evaluated Rate Coefficients for Free-Radical Polymerization, 1. Propagation Rate Coefficient for Styrene. Macromol. Chem. Phys. 1995, 196, 3267-3280. [CrossRef]

80. Nicholson, R.S. Theory and Application of Cyclic Voltammetry for Measurement of Electrode Reaction Kinetics. Anal. Chem. 1965, 37, 1351-1355. [CrossRef]

81. Fawcett, W.R.; Opallo, M. The Kinetics of Heterogeneous Electron Transfer Reaction in Polar Solvents. Angew. Chem. Int. Ed. Engl. 1994, 33, 2131-2143. [CrossRef]

82. Pavan, P.; Lorandi, F.; De Bon, F.; Gennaro, A.; Isse, A.A. Enhancement of the Rate of Atom Transfer Radical Polymerization in Organic Solvents by Addition of Water: An Electrochemical Study. Chem. Electro. Chem. 2021, 8, 2450-2458. [CrossRef]

83. Bortolamei, N.; Isse, A.A.; Di Marco, V.B.; Gennaro, A.; Matyjaszewski, K. Thermodynamic Properties of Copper Complexes Used as Catalysts in Atom Transfer Radical Polymerization. Macromolecules 2010, 43, 9257-9267. [CrossRef]

84. Zerk, T.J.; Bernhardt, P.V. Organo-Copper(II) Complexes as Products of Radical Atom Transfer. Inorg. Chem. 2017, 56, 5784-5792. [CrossRef] [PubMed]

85. Fantin, M.; Lorandi, F.; Ribelli, T.G.; Szczepaniak, G.; Enciso, A.E.; Fliedel, C.; Thevenin, L.; Isse, A.A.; Poli, R.; Matyjaszewski, K. Impact of Organometallic Intermediates on Copper-Catalyzed Atom Transfer Radical Polymerization. Macromolecules 2019, 52, 4079-4090. [CrossRef] 